\title{
PENGARUH KECERDASAN EMOSIONAL PEMIMPIN, MOTIVASI KERJA DAN DISIPLIN KERJA TERHADAP KINERJA PEGAWAI KANTOR PENANAMAN MODAL DAN PELAYANAN TERPADU KABUPATEN AGAM
}

\author{
Mustika Lukman Arief \\ mustikalukmanarief@rocketmail.com \\ Akademi Maritim Sapta Samudra Padang
}

\begin{abstract}
Tujuan dari penelitian ini adalah untuk mempelajari pengaruh kecerdasan emosional, motivasi, dan disiplin pemimpin terhadap kinerja karyawan di Kantor Investasi dan Layanan Terpadu Kabupaten Agam. Populasi dalam penelitian ini berjumlah 41 karyawan. Metode pengumpulan data menggunakan kuesioner dengan Skala Likert 1-5 dan studi dokumentasi. Data yang digunakan dalam penelitian ini adalah data primer dan data sekunder. Teknik analisis data adalah analisis deskriptif.

Semua hipotesis diterima setelah analisis jalur menggunakan SPSS versi 17.Temuan utama dalam penelitian ini adalah motivasi kerja memiliki pengaruh paling dominan terhadap kinerja karyawan $(\beta=0,359)$, yang kedua adalah disiplin kerja $(\beta=0,345)$ dan yang ketiga adalah pemimpin kecerdasan emosi $(\beta=0,239)$. Hasil penelitian ini bahwa variabel kecerdasan emosi pemimpin berpengaruh positif dan signifikan terhadap motivasi kerja, motivasi kerja berpengaruh positif dan signifikan terhadap disiplin kerja, kecerdasan emosi pemimpin berpengaruh positif dan signifikan terhadap disiplin kerja, disiplin kerja berpengaruh positif dan signifikan terhadap kinerja karyawan, pemimpin yang memiliki kecerdasan emosi berpengaruh positif dan signifikan terhadap kinerja karyawan, motivasi kerja berpengaruh positif dan signifikan terhadap kinerja karyawan.
\end{abstract}

Kata Kunci : kecerdasan emosi pemimpin, motivasi kerja, disiplin and kinerja karyawan

\section{Pendahuluan}

\subsection{Latar Belakang}

Kantor Penanaman Modal dan Pelayanan Terpadu (KPMPT) Kabupaten Agam yang dibentuk berdasarkan Peraturan Daerah Kabupaten Agam Nomor 5 Tahun 2011 merupakan unsur pelaksana teknis pemerintah daerah di bidang penanaman modal dan pelayanan terpadu. KPMPT Kabupaten Agam mempunyai tugas pokok dan fungsi memberikan pelayanan di bidang penanaman modal, mulai dari fasilitas informasi berupa potensi, peluang investasi, fasilitasi penyelesaian permasalahan penanaman modal serta pengurusan dan penerbitan perizinan penanaman modal.Berdasarkan pengamatan yang penulis lakukan dan melihat dari hasil penilaian terhadap kinerja pegawai Kantor Penanaman Modal dan Pelayanan Terpadu (KPMPT) Kabupaten Agam, menunjukkan masih ada pegawai yang memiliki nilai kinerja yang cukup atau kurang baik.Beberapa indikasi permasalahan secara umum yang muncul pada KPMPT Kabupaten Agam, antara lain belum optimalnya kegiatan kepemimpinan. Adanya indikasi pimpinan kurang mampu memahami perspektif orang lain dan belum dapat menunjukkan minat aktif terhadap kepentingan bawahan, pimpinan kurang mampu menangani emosi dengan baik ketika berhubungan dengan orang lain dengan cermat membaca situasi dan jaringan sosial, menyatakan pimpinan sering menampakkan kemarahannya tanpa melihat situasi dan kondisi yang ada dan tidak menyadari dampak emosinya tersebut terhadap pegawai, dalam penerapan kedisiplinan, pimpinan menerapkan peraturan yang ketat, seperti jam kerja, namun sering tidak konsisten melaksanakannya, dan pimpinan jarang menghargai partisipasi bawahan dalam 
melaksanakan tugas. Dari indikasi yang terjadi terlihat pimpinan belum mengarahkan kemampuan kecerdasan emosinya dengan optimal dalam menjalankan perannya sebagai seorang pimpinan organisasi, pimpinan belum mampu mengelola emosi, mengontrol, mengatasi dan menempatkan emosinya secara baik dan cerdas dalam membina hubungan dengan orang lain (bawahan).

Permasalahan lain adalah fenomena belum optimalnya motivasi kerja dengan indikasi pegawai jarang mengerjakan tugas tambahan/ekstra dengan senang hati yang diberikan oleh pimpinan,pegawai jarang berupaya memperbaiki kekurangan yang dimiliki, pegawai jarang dan tidak pernah bekerja untuk menjadi yang terbaik di KPMPT Kabupaten Agam, pegawai jarang menambah wawasan sehubungan dengan tugas yang dikerjakan melalui internet sewaktu jam istirahat, dan pegawai sering merasa terganggu atas pengawasan yang dilakukan oleh pimpinan. Dampaknya pegawai bekerja tidak produktif dan cenderung harus dilakukan pengawasan karena jika mengalami kesulitan dalam pelaksanaan tugasnya maka pegawai yang belum memiliki motivasi kerja yang baik akan pergi meninggalkan pekerjaannya dan tidak berusaha untuk mencari solusi untuk mengatasi hambatan pekerjaan yang dihadapinya.

Sehubungan dengan disiplin kerja, diindikasikan antara lain masih terdapat pegawai yang tidak memenuhi ketentuan jam kerja, datang terlambat, pulang cepat dan meninggalkan kantor pada jam kerja, masih ada pegawai yang tidak mengetahui visi dan misi kantor, masih ada pegawai yang beranggapan bahwa pekerjaan yang dibebankan kepadanya tidak sesuai dengan kemampuan dan keterampilan yang dimiliki, masih ditemui pegawai yang tidak pernah menggunakan fasilitas kantor secara efektif dan efisien dalam bekerja, dan masih terdapat pegawai yang kurang memperhatikan penampilan diri sebelum berangkat kerja, kebersihan dan kerapian di tempat kerja. Dari indikasi yang terjadi terlihat bahwa disiplin kerja pegawai di KPMPT Kabupaten Agam belum optimal atau belum sesuai dengan yang diharapkan.

Untuk meningkatkan kinerja pegawai yang ada idealnya organisasi diharapkan terus membina dan memberdayakan pegawai untuk terus meningkatkan kinerjanya. Melihat kondisi hasil penilaian kinerja yang masih belum maksimal tadi, artinya masih banyak pegawai yang belum melaksanakan pekerjaan sebagaimana mestinya dan tentunya akan berdampak pada rendahnya "performance" organisasi sehingga tidak optimalnya pelaksanaan tugas yang harus dijalankan. Untuk itu pimpinan harus mampu mengelola kecerdasan emosionalnya yang akan mampu memberikan Motivasi Kerja dan Disiplin Kerja sehingga berdampak kepada Kinerja Pegawai Kantor Penanaman Modal Dan Pelayanan Terpadu Kabupaten Agam

\subsection{Rmusan Masalah}

Berdasarkan latar belakang yang telah dikemukakan, maka masalah yang dapat dirumuskan sebagai berikut :

1) Apakah Kecerdasan emosional pemimpin berpengaruh positif dan signifikan terhadap motivasi kerja pegawai KPMPT Kabupaten Agam

2) Apakah Motivasi kerja berpengaruh positif dan signifikan terhadap disiplin kerja pegawai KPMPT Kabupaten Agam

3) Apakah Kecerdasan emosional pemimpin berpengaruh positif dan signifikan terhadap disiplin kerja pegawai KPMPT Kabupaten Agam

4) Apakah Disiplin kerja berpengaruh positif dan signifikan terhadap kinerja pegawai KPMPT Kabupaten Agam

5) Apakah Kecerdasan emosional pemimpin berpengaruh positif dan signifikan terhadap kinerja pegawai KPMPT Kabupaten Agam

6) Motivasi kerja berpengaruh positif dan signifikan terhadap kinerja pegawai KPMPT Kabupaten Agam 


\subsection{Tujuan Penelitian}

Hasil dari penelitian ini bertujuan untik mengetahui Pengaruh Kecerdasan Emosional Pemimpin, Motivasi Kerja dan Disiplin Kerja Terhadap Kinerja Pegawai Kantor Penanaman Modal Dan Pelayanan Terpadu Kabupaten Agam

\subsection{Manfaat Penelitian}

Dalam penelitian ini diharapkan dapat digunakan:

1) Bagi Kantor Penanaman Modal Dan Pelayanan Terpadu Kabupaten Agam dapat menjadi masukan bagi peningkatan kinerja karyawan khususnya yang berhubungan dengan motivasi dan disiplin kerja pegawai.

2) Bagi Pimpinan kantor Penanaman Modal Dan Pelayanan Terpadu Kabupaten Agam dapat menjadi masukan bahwa kecerdasan emosional sebagai pemimpin harus bisa dikelola sebaik mungkin agar kinerja pegawai selalu dapat di tingkatkan.

3) Bagi Akademisi dapat dijadikan sebagai bahan acuan yang akan melakukan penelitian dalam bidang yang sama.

4) Bagi Penulis,dapat mennambah wawasan dan pengetahuan sehubungan dengan materi mengenai kecerdasan emosional pimpinan, disipilin kerja dan motivasi kerja pegawai

\section{Tinjauan Teori}

\subsection{Teori Kinerja Pegawai}

Jika dilihat dari asal katanya, kinerja adalah terjemahan dari kata performance, yang menurut The Scribner-Bantam English Dictionary, terbitan Amerika Serikat dan Canada (1979), berasal dari akar kata "to perform" dengan beberapa "entries" yaitu: (1) melakukan,menjalankan, melaksanakan (to do or carry out, execute); (2) memenuhi atau melaksanakan kewajiban suatu niat atau nazar (to discharge of fulfill; as vow); (3) melaksanakan atau menyempurnakan tanggung jawab (to execute or complete an understaking); dan (4) melakukan sesuatu yang diharapkan oleh seseorang atau mesin (to do what is expected of a person machine). Kinerja merupakan suatu kondisi yang harus diketahui dan dikonfirmasikan kepada pihak tertentu untuk mengetahui tingkat pencapaian hasil suatu instansi dihubungkan dengan visi yang diemban suatu organisasi atau perusahaan serta mengetahui dampak positif dan negatif dari suatu kebijakan operasional (Mink, 1993). Selanjutnya (Mink, 1993) mengemukakan pendapatnya bahwa seseorang yang memiliki kinerja tinggi memiliki beberapa karakteristik, yaitu diantaranya: (a) berorientasi pada prestasi, (b) memiliki percaya diri, (c) berpengendalian diri, dan (d) kompetensi.

Kinerja adalah gambaran mengenai tingkat pencapaian pelaksanaan suatu kegiatan, program, dan kebijaksanaan dalam mewujudkan sasaran, tujuan, misi dan visi organisasi yang tertuang dalam perumusan skema strategis (strategic planning) suatu organisasi(Noor, 2019)

Kinerja merupakan perilaku yang secara langsung berhubungan dengan produksi barang dan penyampaian jasa. Informasi tentang kinerja organisasi atau perusahaan merupakan suatu hal yang sangat penting digunakan untuk mengevaluasi apakah proses kinerja yang dilakukan organisasi atau perusahaan salama ini sudah sejalan dengan tujuan yang diharapkan atau belum. Akan tetapi dalam kenyataannya cukup banyak organisasi atau perusahaan justru kurang atau tidak jarang ada yang mempunyai informasi tentang kinerja dalam organisasinya. 


\subsection{Teori Kecerdasan Emosional Pemimpin}

Istilah kecerdasan emosional ( Emotional Intelligent) dikenalkan pertama kali pada tahun 1990 oleh Peter Salovey dari Yale university dan John Meyer dari University of New Hampshire. Kecerdasan emosional sebagai kemampuan memantau dan mengendalikan perasaan sendiri dan orang lain, serta menggunakan perasaan-perasaan itu untuk memandu pikiran dan tindakan. (Goleman, 2005)

Adanya penelitian terhadap 42.000 orang dari 36 negara mengungkapkan hubungan tak terbantahkan antara kecerdasan emosional dan kesuksesan. Steven menggunakan ukuran EQ (Emotional Quotient-kecerdasan emosional) temuan Steven yaitu EQ-I, dan hasilnya tidak ditemukan perbedaan yang signifikan antara rata-rata skor kecerdasan emosional antar etnik. Temuan ini menunjukkan bahwa kelompok etnik manapun dengan latar belakang budaya yang berbeda dapat memanfaatkan EQ-I. Kecerdasan emosional tidak bersifat permanen melainkan dapat ditingkatkan. Semakin tinggi tingkat kecerdasan emosional yang dimiliki seseorang, semakin besar kemungkinan untuk sukses.(Steven, n.d.)

Goleman mengadaptasi model teori Bar On dan Salovey tersebut ke dalam sebuah versi yang menurutnya paling bermanfaat dalam memahami cara kerja kecerdasan emosional dalam kehidupan individu. Adaptasi tentang kecapan emosional dan sosial dikelompokkan menjadi dua bagian yaitu kecakapan pribadi dan kecakapan sosial, sebagai berikut :

a. Kecakapan pribadi, yang meliputi kesadaran diri, pengaturan diri dan motivasi diri.

b. Kecakapan sosial, yang meliputi empati dan keterampilan sosial (Goleman, 2005)

\subsection{Teori Motivasi Kerja}

Motivasi sebagai suatu proses yang menghasilkan suatu intensitas, arah, dan ketekunan individual dalam usaha untuk mencapai suatu tujuan.(S. P. Robbins, 2002a). Unsur kunci dalam definisi adalah intensitas, tujuan, dan ketekunan. Intensitas menyangkut seberapa kerasnya seseorang berusaha. Ini adalah unsur yang paling difokuskan oleh kebanyakan kita bila berbicara tentang motivasi. Akan tetapi intensitas yang tidak akan membawa hasil yang diinginkan kecuali kalau upaya itu diarahkan ke suatu tujuan yang menguntungkan organisasi. Oleh karena itu kita harus memperhitungkan kualitas dari upaya itu maupun intensitasnya. Akhirnya motivasi memiliki dimensi ketekunan. Ini adalah ukuran tentang berapa lama seseorang dapat mempertahankan usahanya. Individu-individu yang termotivasi tetap bertahan pada pekerjaan cukup lama untuk mencapai tujuan mereka. Adapun tujuan dari motivasi adalah sebagai berikut (S . M. Hasibuan, 2001) :

a. Meningkatkan moral dan kepuasan kerja pegawai.

b. Meningkatkan produktivitas kerja pegawai.

c. Mempertahankan kestabilan pegawai perusahaan.

d. Meningkatkan kedisiplinan pegawai.

e. Mengefektifkan pengadaan pegawai.

f. Menciptakan suasana dan hubungan kerja yang baik.

g. Meningkatkan loyalitas, kreatifitas dan partisipasi pegawai.

h. Meningkatkan kesejahteraan pegawai.

i. Memperkuat rasa tanggung jawab terhadap tugas pegawai.

j. Meningkatkan efisiensi penggunaan alat-alat dan bahan baku. 


\subsection{Teori Disiplin Kerja}

Disiplin kerja secara umum dapat diartikan sebagai suatu ketaatan pada aturan kerja atau prosedur yang telah ditetapkan. Disiplin harus ditegakkan dalam suatu organisasi/perusahaan, karena tanpa dukungan disiplin yang baik, sulit bagi perusahaan untuk mewujudkan tujuannya (M. Hasibuan, 2001). Disiplin kerja juga merupakan suatu keadaan tertib karen orang - oran yang bergabung dalam organisasi tunduk dan taat pada peraturan yang ada dan melaksanakannya dengan senang hati. (Finna Okta Maulina, Yusuf, \& Priyatama, 2015). Selain itu "Dicipline is management action to enforce organization standar" (Disiplin kerja diartikan sebagai pelaksanaan manajemen untuk memperteguh pedoman-pedoman organisasi) (Anwar Prabu Mangkunegara, 2011)

Tinggi rendahnya tingkat kedisipinan kerja karyawan dapat dilihat dari tingkat absensi dan tingkah laku karyawan dalam mengerjakan tugas - tugasnya. Tingkat absensi yang tinggi menandakan tingkat disiplin kerja karyawan dalam perusahaan rendah, sebaliknya semakin rendah tingkat absensi karyawan berarti disiplin kerja karyawan dalam perusahaan tinggi, dalam hal ini akan sangat membantu perusahaan untuk mencapai sasaran dan tujuannya.(Ratnasari, 2018). Disiplin juga merupakan kesadaran dan kemauan seseorang untuk mematuhi semua hukum dan norma sosial yang berlaku. (Yadewani \& Wijaya, 2019). Sehingga dapat dikatakan bahwa disiplin merupakan hal yang mutlak untuk di ikuti oleh seluruh karyawan.

Disiplin sangat diperlukan untuk mengontrol manajemen. Idealnya harus disajikan sebagai sebuah mekanisme perbaikan untuk menciptakan dan memelihara produktif dan mau mendengarkan tenaga kerja. Bentuk disiplin kerja yang baik akan tergambar pada suasana sebagai berikut: (Gaouzali, 2000)

a. Tingginya rasa kepedulian pegawai terhadap pencapaian tujuan yang ingin dicapai.

b. Tingginya semangat dan gairah kerja dan inisiatif kerja pegawai dalam melakukan kerjanya.

c. Besarnya rasa tanggung jawab para pegawai untuk melaksanakan tugas dengan sebaik-baiknya

d. Berkembangnya rasa memiliki dan rasa solidaritas yang tinggi di kalangan pegawai.

e. Meningkatkan efisiensi dan produktifitas kerja.

\section{Metode Penelitian}

\subsection{Populasi dan Sampel}

Populasi dalam penelitian ini adalah semua pegawaiKantor Penanaman Modal dan Pelayanan Terpadu Kabupaten Agam sebanyak 41 orang.Formulasi yang digunakan untuk untuk penentuan sampel adalah formulasi Isaac dan Mitchel, yaitu : populasi $=$ sampel. Maka sampel yang diambil adalah sebanyak 41 responden .

\subsection{Jenis Data dan Sumber Data}

Sumber data yang digunakan dalam penelitian ini adalah Data primer yang diperoleh dan dikumpulkan peneliti secara langsung dari jawaban responden atas kuesioner yang diberikan kepada para pegawai Kantor Penanaman Modal dan Pelayanan Terpadu Kabupaten Agam.Data sekunder merupakan data yang diperoleh dari Bagian Tata Usaha dan Kepegawaian Kantor Penanaman Modal dan Pelayanan Terpadu Kabupaten Agam meliputi jumlah karyawan, golongan/kepangkatan, bezetting pegawai, penilaian kinerja, laporan akuntabilitas dan kinerja instansi pemerintah (LAKIP). 


\subsection{Variabel Penelitian}

Variabel penelitian dikelompokkan menjadi variabel eksogen (kecerdasan emosional pemimpin, motivasi kerja dan disiplin kerja) dan variabel endogen (kinerja). Obyek penelitian adalah semua pegawai di lingkungan kantor Penanaman Modal dan Pelayanan Terpadu Kabupaten Agam.Penelitian ini terdiri dari 4 variabel, terdiri dari 1 variabel endogen dan 3 variabel eksogen. Variabel endogen adalah : Kinerja Pegawai (Y) sedangkan variabel eksogen yang dimaksud adalah : Kecerdasan Emosional Pemimpin (X1), Motivasi Kerja (X2) dan Disiplin Kerja (X3).

\subsection{Hipotesis}

H1 : Kecerdasan emosional pemimpin berpengaruh positif dan signifikan terhadap motivasi kerja pegawai KPMPT Kabupaten Agam

$\mathrm{H} 2$ : Motivasi kerja berpengaruh positif dan signifikan terhadap disiplin kerja pegawai KPMPT Kabupaten Agam

H3 : Kecerdasan emosional pemimpin berpengaruh positif dan signifikan terhadap disiplin kerja pegawai KPMPT Kabupaten Agam

H4 ; Disiplin kerja berpengaruh positif dan signifikan terhadapa kinerja pegawai KPMPT Kabupaten Agam

H5 : Kecerdasan emosional pemimpin berpengaruh positif dan signifikan terhadap kinerja pegawai KPMPT Kabupaten Agam

H6 : Motivasi kerja berpengaruh positif dan signifikan terhadap kinerja pegawai KPMPT Kabupaten Agam

\subsection{Kerangka Penelitian}

Model analisis data adalah metode analisis jalur (Path Analysis), untuk menerangkan pengaruh langsung dan pengaruh tidak langsung seperangkat variabel eksogen terhadap variabel endogen.

Hasil besaran diagram jalur menunjukkan besarnya pengaruh masing- masing variabel eksogen terhadap variabel endogen yang disebut koefisien jalur, dengan diagram jalur sebagai berikut :

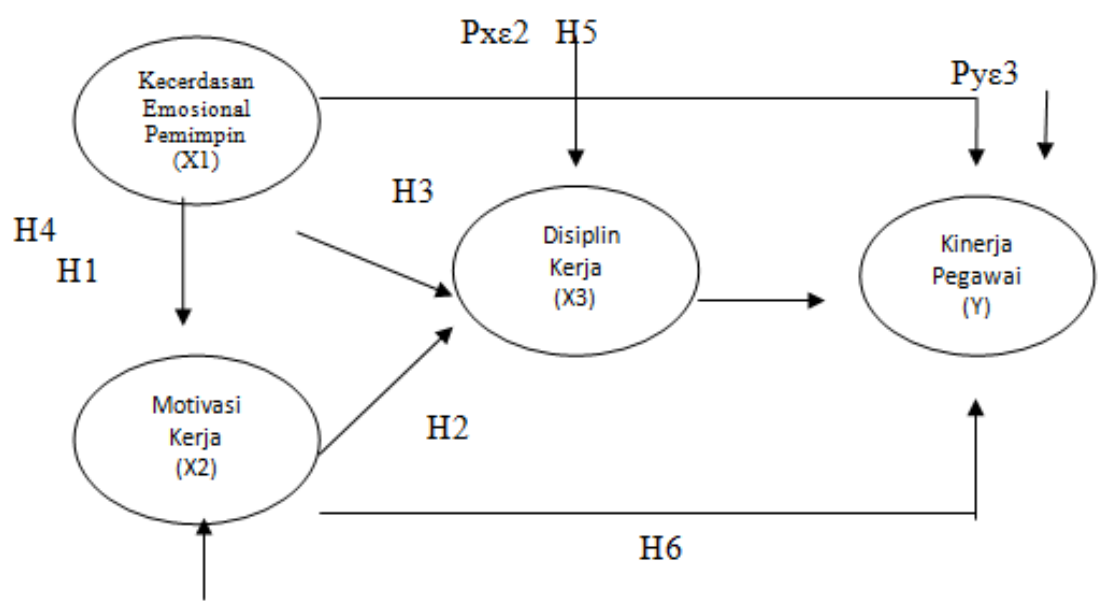

Gambar 1. Kerangka Konsep Penelitian 


\section{Hasil Penelitian Dan Pembahasan}

\subsection{Uji Homogenitas}

Uji homogenitas, yaitu uji yang dilakukan untuk melihat apakah data yang diperoleh berasal dari sampel yang homogen. Uji homogenitas variansi populasi dilakukan dengan Test of homogenity of variance. Hasil perhitungan uji homogenitas dapat diikuti pada tabel 1 berikut:

Tabel 1. Rangkuman Uji Homogenitas Variabel Penelitian

\begin{tabular}{|l|c|c|c|c|c|}
\hline \multicolumn{1}{|c|}{ Variabel } & $\begin{array}{c}\text { Levene } \\
\text { Statistik }\end{array}$ & Df 1 & Df 2 & Sig & Ket. \\
\hline $\begin{array}{l}\text { Kecerdasan Emosional } \\
\text { Pemimpin-Kinerja }\end{array}$ & 2.184 & 10 & 23 & 0,059 & Homogen \\
\hline Motivasi Kerja - Kinerja & 2.119 & 10 & 23 & 0,066 & Homogen \\
\hline Disiplin Kerja - Kinerja & 2.126 & 10 & 25 & 0,061 & Homogen \\
\hline
\end{tabular}

Sumber : Pengolahan Data Primer

Dari Tabel V.1 dapat dilihat masing-masing skor signifikansi variabel kecerdasan emosional pemimpin sebesar 0,059, motivasi kerja sebesar 0,066 disiplin kerja sebesar 0,061. Hal ini berarti skor masing-masing variabel lebih besar dari taraf signifikansi 0,05. Berdasarkan skor ini, dapat dikatakan bahwa sebaran data berasal dari sampel yang homogen.

\subsection{Hasil Uji Hipotesis}

Untuk menentukan apakah hipotesis yang diajukan sebelumnya dapat diterima atau ditolak, maka digunakan dasar untuk menerima atau menolak hipotesis tersebut, dengan kriteria :

Ho ditolak jika nilai $\mathrm{t}=0$ atau Sig. observasi $>0,05$

Ho diterima jika nilai $t>0$ atau Sig. observasi $<0,05$

a. Hipotesis kesatu : Kecerdasan emosional pemimpin berpengaruh signifikan terhadap motivasi kerja pegawai Kantor Penanaman Modal dan Pelayanan Terpadu Kabupaten Agam.

Berdasarkan hasil analisa yang telah dihitung diperoleh nilai t sebesar 3,424 pada signifikansi 0,001 < 0,05. Dengan memperhatikan kedua hasil tersebut, maka Ho ditolak. Artinya kecerdasan emosional pemimpin berpengaruh signifikan terhadap motivasi kerja pegawai Kantor Penanaman Modal dan Pelayanan Terpadu (KPMPT) Kabupaten Agam.

b. Hipotesis kedua : motivasi kerja berpengaruh signifikan terhadap disiplin kerja pegawai Kantor PMPT Kabupaten Agam.

Berdasarkan hasil analisa yang telah dihitung diperoleh nilai t sebesar 3,497 pada signifikansi 0,001 < 0,05. Dengan memperhatikan kedua hasil tersebut, maka Ho ditolak. Artinya motivasi kerja berpengaruh signifikan terhadap disiplin kerja pegawai Kantor Penanaman Modal dan Pelayanan Terpadu (KPMPT) Kabupaten Agam.

c. Hipotesis ketiga : Kecerdasan Emosional Pemimpin berpengaruh signifikan terhadap Disiplin Kerja pegawai KPMPT Kabupaten Agam.

Berdasarkan hasil analisa yang telah dihitung diperoleh nilai $t$ sebesar 2,135 pada signifikansi 0,039<0,05. Dengan memperhatikan kedua hasil tersebut, maka Ho ditolak. Artinya kecerdasan emosional pemimpin berpengaruh signifikan terhadap disiplin kerja pegawai Kantor Penanaman Modal dan tPelayanan Terpadu (KPMPT) Kabupaten Agam. 
d. Hipotesis keempat : Disiplin Kerja berpengaruh signifikan terhadap Kinerja pegawai KPMPT Kabupaten Agam.

Berdasarkan hasil analisa yang telah dihitung diperoleh nilai t sebesar 2,117 pada signifikansi 0,041 < 0,05. Dengan memperhatikan kedua hasil tersebut, maka Ho ditolak. Artinya disiplin Kerja berpengaruh signifikan terhadap Kinerja pegawai Kantor Penanaman Modal dan Pelayanan Terpadu (KPMPT) Kabupaten Agam.

e. Hipotesis kelima : Kecerdasan emosional pemimpin berpengaruh signifikan terhadap Kinerja pegawai KPMPT Kabupaten Agam.

Berdasarkan hasil analisa yang telah dihitung diperoleh nilai t sebesar 2,055 pada signifikansi 0,047 < 0,05. Dengan memperhatikan kedua hasil tersebut, maka Ho ditolak. Artinya kecerdasan emosional pemimpin berpengaruh signifikan terhadap kinerja pegawai Kantor Penanaman Modal dan Pelayanan Terpadu (KPMPT) Kabupaten Agam.

f. Hipotesis keenam : Motivasi kerja berpengaruh signifikan terhadap Kinerja pegawai KPMPT Kabupaten Agam.

Berdasarkan hasil analisa yang telah dihitung diperoleh nilai t sebesar 2,293 pada signifikansi 0,028 < 0,05. Dengan memperhatikan kedua hasil tersebut, maka Ho ditolak. Artinya motivasi kerja berpengaruh signifikan terhadap Kinerja pegawai Kantor Penanaman Modal dan Pelayanan Terpadu (KPMPT) Kabupaten Agam.

Pengaruh langsung dan Tidak Langsung Variabel Eksogen [Kecerdasan Emosional Pemimpin $\left(\mathrm{X}_{1}\right)$, Motivasi Kerja $\left(\mathrm{X}_{2}\right)$ dan Disiplin Kerja $\left(\mathrm{X}_{3}\right)$ ] terhadap Variabel Endogen \{Kinerja Pegawai(Y)]:

\section{a. Variabel Kecerdasan Emosional Pemimpin (X1)}

Pengaruh langsung :

$\mathrm{X}_{1}$ terhadapX $\mathrm{X}_{2}$

$\mathrm{X}_{1}$ terhadap $\mathrm{Y}$

Pengaruh tidak langsung

$\mathrm{X}_{1}$ terhadap $\mathrm{Y}$ melalui $\mathrm{X}_{2}$

$\mathrm{X}_{1}$ terhadap $\mathrm{Y}$ melalui $\mathrm{X}_{3}$

$$
\begin{aligned}
& =\mathrm{X}_{2} \mathrm{X}_{1} \leftarrow \mathrm{X}_{2} \rightarrow \\
& =\left(\mathrm{Px}_{2} \mathrm{X}_{1}\right)\left(\mathrm{Px}_{2} \mathrm{X}_{1}\right) \\
& =(0,481)(0,481) \\
& =0,2314 \\
& =23,14 \% \\
& =\mathrm{Y} \leftarrow \mathrm{X}_{1} \rightarrow \mathrm{Y} \\
& =\left(\mathrm{Pyx}_{1}\right)\left(\mathrm{Pyx}_{1}\right) \\
& =(0,239)(0,239) \\
& =0,0571 \\
& =5,71 \%
\end{aligned}
$$$$
=\mathrm{Y} \longleftarrow \mathrm{X}_{1} \Omega \mathrm{X}_{2} \rightarrow \mathrm{Y}
$$$$
=\left(\mathrm{Pyx}_{1}\right)\left(\mathrm{Px}_{2} \mathrm{x}_{1}\right)\left(\mathrm{Pyx}_{2}\right)
$$$$
=(0,239)(0,481)(0,359)
$$$$
=0,0413
$$$$
=4,13 \%
$$$$
=\mathrm{Y} \leftarrow \mathrm{X}_{1} \Omega \mathrm{X}_{3} \rightarrow \mathrm{Y}
$$$$
=\left(\mathrm{Pyx}_{1}\right)\left(\mathrm{Px}_{3} \mathrm{x}_{1}\right)\left(\mathrm{Pyx}_{3}\right)
$$$$
=(0,239)(0,293)(0,345)
$$$$
=0,0242
$$$$
=2,42 \%
$$

$\mathrm{X}_{1}$ terhadap $\mathrm{Y}$ melalui $\mathrm{X}_{2}$ dan $\mathrm{X}_{3}=\mathrm{Y} \leftarrow\left(\mathrm{X}_{1} \Omega \mathrm{X}_{3}\left(\mathrm{X}_{1} \Omega \mathrm{X}_{3)} \rightarrow \mathrm{Y}\right.\right.$

$$
\begin{aligned}
& =\left(\mathrm{Pyx}_{1}\right)\left(\mathrm{Px}_{2} \mathrm{X}_{1}\right)\left(\mathrm{Px}_{3} \mathrm{X}_{1}\right)\left(\mathrm{Pyx}_{3}\right) \\
& =(0,239)(0,481)(0,293)(0,345) \\
& =0,0116=1,16 \%
\end{aligned}
$$


Pengaruh variabel lain $\left(P x_{2} \varepsilon_{1}\right)$ terhadap motivasi kerja

$$
\begin{aligned}
& \left(P x_{2} \varepsilon_{1}\right)=\sqrt{1 \quad \mathrm{R}^{2} \mathrm{Yx}_{1} \mathrm{x}_{2} \mathrm{x}_{3}} \\
& \left(P x_{2} \varepsilon_{1}\right)=\sqrt{(1 \quad 0,231} \\
& \left(P x_{2} \varepsilon_{1}\right)=\sqrt{(0,769}=0,7516
\end{aligned}
$$

\section{b. Variabel Motivasi Kerja (X2)}

Pengaruh langsung

$\mathrm{X}_{2}$ terhadap $\mathrm{Y}$

$$
\begin{aligned}
& =\mathrm{Y} \leftarrow \mathrm{X}_{2} \rightarrow \mathrm{Y} \\
& =\left(\mathrm{Pyx}_{2}\right)\left(\mathrm{Pyx}_{2}\right) \\
& =(0,359)(0,359) \\
& =0,1289 \\
& =12,89 \%
\end{aligned}
$$

Pengaruh tidak langsung :

$\mathrm{X}_{2}$ terhadap $\mathrm{Y}$ melalui $\mathrm{X}_{3}$

$$
\begin{aligned}
& =\mathrm{Y} \Vdash \mathrm{X}_{2} \Omega \mathrm{X}_{3} \rightarrow \mathrm{Y} \\
& =\left(\mathrm{Pyx}_{2}\right)\left(\mathrm{Px}_{3} \mathrm{X}_{2}\right)\left(\mathrm{Pyx}_{3}\right) \\
& =(0,359)(0,480)(0,345) \\
& =0,0595 \\
& =5,95 \%
\end{aligned}
$$

Pengaruh variabel lain $\left(P x_{3} \varepsilon_{2}\right)$ terhadap motivasi kerja

$$
\begin{aligned}
& \left(P x_{3} \varepsilon_{2}\right)=\sqrt{1 \quad \mathrm{R}^{2} \mathrm{Yx}_{1} \mathrm{x}_{2} \mathrm{x}_{3}} \\
& \left(P x_{3} \varepsilon_{2}\right)=\sqrt{(1 \quad 0,451} \\
& \left(P x_{3} \varepsilon_{2}\right)=\sqrt{(0,549}=0,7409
\end{aligned}
$$

\section{c. Variabel Disiplin Kerja (X3)}

Pengaruh langsung :

$\mathrm{X}_{3}$ terhadap $\mathrm{Y}$

$$
\begin{aligned}
& =\mathrm{Y} \leftarrow \mathrm{X}_{3} \rightarrow \mathrm{Y} \\
& =\left(\mathrm{Pyx}_{3}\right)\left(\mathrm{Pyx}_{3}\right) \\
& =(0,345)(0,345) \\
& =0,1190 \\
& =11,9 \%
\end{aligned}
$$

Pengaruh variabel lain $\left(\mathrm{Py} \varepsilon_{3}\right)$ terhadap disiplin kerja

$$
\begin{aligned}
& \left(\mathrm{Py} \varepsilon_{3}\right)=\sqrt{1 \quad \mathrm{R}^{2} \mathrm{Yx}_{1} \mathrm{x}_{2} \mathrm{x}_{3}}
\end{aligned}
$$

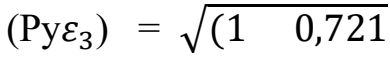

$$
\begin{aligned}
& \left(\mathrm{Py} \varepsilon_{3}\right)=\sqrt{(0,279}=0,5282
\end{aligned}
$$

Keseluruhan interpretasi pengaruh langsung dan tidak langsung diatas dapat diringkas dan ditampilkan dalam Tabel 2 berikut ini : 
Tabel 2.

Ringkasan Interpretasi Pengaruh Langsung dan Tidak Langsung

\begin{tabular}{|c|c|c|c|}
\hline No & Keterangan & $\%$ & $\begin{array}{c}\text { Total } \\
(\%)\end{array}$ \\
\hline 1 & 2 & 3 & 4 \\
\hline 1 & $\begin{array}{l}\text { Pengaruh langsung kecerdasan emosional } \\
\text { pemimpin terhadap motivasi kerja }\end{array}$ & 23,14 & \\
\hline 2 & $\begin{array}{l}\text { Pengaruh langsung kecerdasan emosional } \\
\text { pemimpin terhadap kinerja }\end{array}$ & 5,71 & \\
\hline \multirow[t]{2}{*}{3} & $\begin{array}{l}\text { Pengaruh tidak langsung kecerdasan emosional } \\
\text { pemimpin terhadap kinerja pegawai melalui } \\
\text { disiplin kerja }\end{array}$ & 4,13 & \\
\hline & $\begin{array}{l}\text { Total pengaruh langsung dan tidak langsung } \\
\text { variabel kecerdasan emosional pemimpin } \\
\text { terhadap kinerja pegawai }\end{array}$ & & 32,98 \\
\hline 1 & 2 & 3 & 4 \\
\hline 4 & $\begin{array}{l}\text { Pengaruh langsung motivasi kerja terhadap } \\
\text { kinerja pegawai }\end{array}$ & 12,89 & \\
\hline \multirow[t]{2}{*}{5} & $\begin{array}{l}\text { Pengaruh tidak langsung motivasi kerja } \\
\text { terhadap kinerja pegawai melalui disiplin kerja }\end{array}$ & 5,95 & \\
\hline & $\begin{array}{l}\text { Total pengaruh langsung dan tidak langsung } \\
\text { variabel motivasi kerja terhadap kinerja } \\
\text { pegawai }\end{array}$ & & 18,84 \\
\hline \multirow[t]{3}{*}{6} & $\begin{array}{l}\text { Pengaruh langsung disiplin kerja terhadap } \\
\text { kinerja pegawai }\end{array}$ & 11,9 & \\
\hline & $\begin{array}{l}\text { Total pengaruh langsung variabel disiplin } \\
\text { kerja terhadap kinerja pegawai }\end{array}$ & & 11,9 \\
\hline & $\begin{array}{l}\text { Total pengaruh variabel eksogeterhadap } \\
\text { variabel endogen }\end{array}$ & & 63,72 \\
\hline 7 & $\begin{array}{l}\text { Pengaruh variabel-variabel lain terhadap } \\
\text { kinerja pegawai }\end{array}$ & & 36,28 \\
\hline
\end{tabular}

Sumber : Pengolahan Data Primer, 2019

\subsection{Hasil Analisis Jalur}

Berdasarkan hasil analisis dan pembahasan yang telah diuraikan, maka diperoleh struktur analisis jalur antara variabel eksogen dan variabel endogen sebagai berikut :

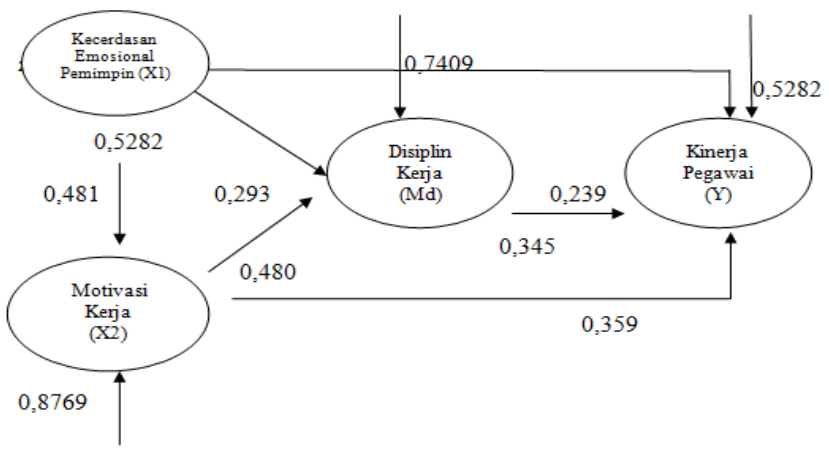

Gambar. 2 Struktur Analisis Jalur 
Dari gambar 2 struktur analisis jalur diatas, dan dengan memperhatikan koefisien jalurnya maka untuk meningkatkan kinerja pegawai menjadi lebih baik akan lebih efektif jika pimpinan (Kepala) Kantor Penanaman Modal dan Pelayanan Terpadu (KPMPT) Kabupaten Agam meningkatkan kecerdasan emosionalnya menjadi lebih baik lagi yang sekaligus akan menginspirasi bawahan untuk mengoptimalkan motivasi kerja pegawai dan diringi dengan pembangunan disiplin kerja yang baik, ini menjadi hal yang sangat penting untuk dilakukan.

Berdasarkan hasil koefisien jalur masing-masing variabel eksogen terhadap variabel endogen, dalam penelitian ini variabel motivasi kerja memiliki pengaruh terbesar $(0,359)$ terhadap variabel kinerja dalam penelitian ini, dibandingkan variabel disiplin kerja $(0,345)$ dan variabel kecerdasan emosional pemimpin $(0,239)$. Dengan memperhatikan karakteristik responden yang mayoritas berusia 31-35 tahun sebanyak $31,72 \%$, sedangkan sisanya $69,28 \%$ berusia lebih dari 35 tahun dan kurang dari 31 tahun, dan dengan melihat masa kerja yang mayoritas 6-10 tahun (36,59\%), mayoritas berpendidikan Sarjana dan SMA (masing-masing 34,15\%), serta mayoritas responden sudah mencapai pangkat Penata Golongan III mengindikasikan responden sudah mulai kurang bersemangat dan jenuh melaksanakan tugas dan pekerjaannya, menurunnya ketekunan dan kurangnya upaya untuk menambah wawasan pengetahuan dan keterampilan untuk menunjang pelaksanaan tugas.

Hal ini berdampak pada penurunan disiplin pegawai. Pegawai dalam bekerja tidak mematuhi peraturan disiplin. Datang terlambat, pulang cepat dan meninggalkan tugas pada jam kerja, tidak efisien dan efektif dalam menggunakan fasilitas kerja, serta tidak mematuhi standar kerja yang telah ditetapkan. Dalam hal pengaruh variabel kecerdasan emosional pemimpin dalam penelitian ini yang koefisien jalurnya terkecil, dan dengan melihat mayoritas responden berjenis kelamin laki-laki $(60,96 \%)$ dapat dikatakan bahwa pegawai laki-laki dalam melaksanakan tugas dan pekerjaannya lebih mengedepankan rasio dalam berpikir dibandingkan emosi dan perasaan.

\section{Kesimpulan Dan Saran}

\subsection{Kesimpulan}

Berdasarkan temuan penelitian dan pembahasan pada Bab IV sebelumnya, maka dalam penelitian ini dapat diambil beberapa kesimpulan, antara lain :

1) Kecerdasan emosional pemimpin berpengaruh signifikan terhadap motivasi kerja pegawai Kantor Penanaman Modal dan Pelayanan Terpadu (KPMPT) Kabupaten Agam. Hasil penelitian ini mendukung teori (Salovey, P \& Mayer, 1999), (S. Robbins, 1999), yang menunjukkan bahwa untuk meningkatkan motivasi kerja pegawai Kantor Penanaman Modal dan Pelayanan Terpadu (KPMPT) Kabupaten Agam, maka dapat dilakukan peningkatan kecerdasan emosional pemimpin.

2) Motivasi kerja berpengaruh signifikan terhadap disiplin kerja pegawai Kantor Penanaman Modal dan Pelayanan Terpadu (KPMPT) Kabupaten Agam. Hasil penelitian ini mendukung teori (Handoko, 1992),(Ermaya, 1996), (Martoyo, 1996). Hasil deskripsi data variabel motivasi kerja dan disiplin kerja berada pada kriteria "kurang". Hal ini menunjukkan bahwa untuk meningkatkan disiplin kerja pegawai Kantor Penanaman Modal dan Pelayanan Terpadu (KPMPT) Kabupaten Agam, maka dapat dilakukan dengan peningkatan motivasi kerja pegawai.

3) Kecerdasan emosional pemimpin berpengaruh signifikan terhadap disiplin kerja pegawai Kantor Penanaman Modal dan Pelayanan Terpadu (KPMPT) Kabupaten Agam. Hasil penelitian ini mendukung teori Edwin A. Lock (2008). Hasil deskripsi data variabel kecerdasan emosional pemimpin dan disiplin kerja berada pada kriteria "kurang". Hal ini menunjukkan bahwa untuk meningkatkan disiplin kerja 
pegawai Kantor Penanaman Modal dan Pelayanan Terpadu (KPMPT) Kabupaten Agam, maka dapat dilakukan peningkatan kecerdasan emosional pemimpin.

4) Disiplin kerja berpengaruh signifikan terhadap kinerja pegawai Kantor Penanaman Modal dan Pelayanan Terpadu (KPMPT) Kabupaten Agam. Hasil penelitian ini mendukung teori (Abdurrahmat, 2006).Hasil deskripsi data variabel disiplin kerja berada pada kriteria "kurang" dan varibel kinerja berada pada kriteria "cukup". Hal ini menunjukkan bahwa untuk meningkatkan kinerja pegawai Kantor Penanaman Modal dan Pelayanan Terpadu (KPMPT) Kabupaten Agam, maka dapat dilakukan dengan pembangunan dan peningkatan disiplin kerja pegawai.

5) Kecerdasan emosional pemimpin berpengaruh signifikan terhadap kinerja pegawai Kantor Penanaman Modal dan Pelayanan Terpadu (KPMPT) Kabupaten Agam. Hasil penelitian ini mendukung teori(Kenneth N, 1992). Hasil deskripsi data variabel kecerdasan emosional pemimpin berada pada kriteria "kurang" dan variabel kinerja berada pada kriteria "cukup". Hal ini menunjukkan bahwa untuk meningkatkan kinerja pegawai Kantor Penanaman Modal dan Pelayanan Terpadu (KPMPT) Kabupaten Agam, maka dapat dilakukan dengan peningkatan kecerdasan emosional pemimpin.

6) Motivasi kerja berpengaruh signifikan terhadap kinerja pegawai Kantor Penanaman Modal dan Pelayanan Terpadu (KPMPT) Kabupaten Agam. Hasil penelitian ini mendukung teori (S. P. Robbins, 2002b).Hasil deskripsi data variabel motivasi kerja berada pada kriteria "kurang" dan variabel kinerja berada pada kriteria "cukup". Hal ini menunjukkan bahwa untuk meningkatkan kinerja pegawai Kantor Penanaman Modal dan Pelayanan Terpadu (KPMPT) Kabupaten Agam, maka dapat dilakukan dengan peningkatan motivasi kerja pegawai.

7) Variabel motivasi kerja memiliki pengaruh yang dominan $(0,359)$ terhadap kinerja yang diikuti oleh disiplin kerja $(0,345)$ dan kecerdasan emosional pemimpin $(0,239)$.

\subsection{Saran}

Berdasarkan kesimpulan diatas, maka untuk meningkatkan kinerja pegawai Kantor Penanaman Modal dan Pelayanan Terpadu (KPMPT) Kabupaten Agam dapat disarankan beberapa hal sebagai berikut :

1) Kepada pimpinan Kantor Penanaman Modal dan Pelayanan Terpadu (KPMPT) Kabupaten Agam untuk dapat meningkatkan lagi kecerdasan emosionalnya, diantaranya kepemimpinan atasan menginspirasi bawahan yakni membimbing dan memotivasi dengan visi yang semangat, mengembangkan bawahan dengan menunjang kemampuan bawahan melalui umpan balik dan bimbingan, optimis dalam memperjuangkan suatu sasaran/tujuan walaupun ada halangan/kegagalan, mampu menangani emosi dengan baik ketika berhubungan dengan orang lain, memprakarsai, mengelola, dan memimpin di arah yang baru. Disamping itu pimpinan Kantor Penanaman Modal dan Pelayanan Terpadu (KPMPT) Kabupaten Agam juga diminta untuk meningkatkan motivasi dan disiplin kerja pegawainya dengan cara :

a. Memberikan kebebasan yang bertanggung jawab dari setiap pegawai untuk menyelesaikan pekerjaannya, sehingga pegawai tidak merasa diperintah dan diawasi secara formal dari pimpinan

b. Membantu pegawai untuk menemukan kemampuannya sendiri untuk dikembangkan dan dihargai

c. Memberi kesempatan untuk memperbaiki kesalahan yang diperbuat dengan meningkatkan teknik-teknik yang lebih efektif dan efisien.

d. Pimpinan memberikan rewards (penghargaan) terhadap prestasi kerja yang telah ditunjukkan oleh pegawai. 
e. Membudayakan senyum, sapa dan salam untuk meningkatkan hubungan kerja seluruh pegawai.

f. Pimpinan Kantor Penanaman Modal dan Pelayanan Terpadu (KPMPT) Kabupaten Agam hendaknya memimpin dengan keteladanan perbuatan bukan hanya lewat perkataan.

2) Kepada pimpinan di tingkat seksi (kepala seksi/tata usaha) agar membenahi kinerja pegawai dengan prioritas meningkatkan motivasi kerja yang lebih baik dengan cara :

a. Menumbuhkan dan memelihara hubungan kerja yang baik, membimbing dan mengarahkan bawahan sehingga membangkitkan motivasi kerja menjadi lebih optimal lagi.

b. Meningkatkan ketekunan, memotivasi diri sendiri, tetap bekerja walaupun tanpa pengawasan dari pimpinan, dengan menyediakan fasilitas kerja yang memadai sesuai dengan perkembangan ilmu pengetahuan dan teknologi.

c. Mendorong bawahan untuk berani menghadapi tantangan pekerjaan dan mau memberikan kontribusi baik berupa pendapat terhadap perbaikan organisasi dan perbaikan cara kerja pegawai yang sesuai dengan standar kerja yang ditetapkan organisasi.

d. Memberikan insentif yang sesuai dengan kinerja yang telah dihasilkan pegawai

3) Untuk peningkatan dan pembangunan disiplin pegawai Kantor Penanaman Modal dan Pelayanan Terpadu Kabupaten Agam, perlu dilakukan hal-hal sebagai berikut :

a. Dalam menerapkan peraturan disiplin, Pimpinan Kantor Penanaman Modal dan Pelayanan Terpadu (KPMPT) Kabupaten Agam hendaknya menjadi contoh/keteladanan dalam tingkah laku dan perbuatan.

b. Adanya keberanian dari Pimpinan KPMPT Kabupaten Agam untuk memberikan punishment (sanksi) yang tegas dan seimbang terhadap pelanggaran disiplin yang dilakukan oleh pegawai sehingga memberikan efek jera dan peringatan kepada pegawai lain yang akan melakukan tindakan tidak disiplin.

c. Pimpinan selalu melakukan pengawasan dan pengendalian terhadap pelaksanaan tugas yang dilakukan oleh pegawai untuk mengantisipasi terjadinya tindakan indisipliner.

d. Pimpinan selalu melakukan pengawasan terhadap kehadiran pegawai dalam melaksanakan tugas antara lain dengan selalu melakukan pengecekan terhadap keberadaan pegawai selama jam kerja.

4) Dari hasil penelitian diketahui ada variabel-variabel lain yang diduga dapat mempengaruhi kinerja pegawai sesuai dengan teori yang diberikan oleh para pakar seperti variabel : faktor individu (integritas yang tinggi, konsentrasi diri yang baik, kemampuan potensi, yaitu kecerdasan pikiran/Inteligensi Quotient/ IQ ) dan faktor lingkungan kerja organisasi ( uraian jabatan, autoritas yang memadai, target kerja yang menantang, komunikasi kerja, hubungan kerja, iklim kerja, peluang berkarir dan fasilitas kerja), gaji, keamanan dan perlindungan dalam bekerja, penghayatan atas maksud dan makna pekerjaan, promosi dan pengembangan diri pegawai, keterlibatan dalam organisasi, kepimpinan dan kesetiaan. Kepada peneliti yang berminat untuk mengembangkan penelitian ini tentunya dapat menggunakan variabel-variabel tersebut. 


\section{Daftar Pustaka}

Abdurrahmat, F. (2006). Manaje men Sumber Daya Manusia. Bandung: Rineka Cipta.

Anwar Prabu Mangkunegara. (2011). Manajemen Sumber Daya ManusiaPerusahaan. Bandung: PT. Remaja Rosdakarya Offset.

Ermaya, S. (1996). The Relationship Between Leadership Style and Employee Performance. Singaporean Journal of Business Eco Nomics, and Management Studies, 2, 51-53.

Finna Okta Maulina, Yusuf, M., \& Priyatama, A. N. (2015). Hubungan antara budaya kerja dan disiplin kerja dengan kepuasan kerja pada karyawan Bagian Umum Pemerintah Kota Tegal. Jurnal Ilmiah Psikologi Candrajiwa, 4, 235-244. Retrieved from http:/ /candrajiwa.psikologi.fk.uns.ac.id/index.php/candrajiwa/article/view/116

Gaouzali, S. (2000). Manajemen Sumber Daya Manusia (Suatu Pendekatan. Mikro). Jakarta: Djambatan.

Goleman, D. (2005). Kecerdasan. Emosional Mengapa EI lebih Penting Daripada IQ. Jakarta: PT.Gramedia.

Handoko, M. (1992). Motivasi Daya Penggerak Tingkah Laku. Yogyakarta: Kanisius. Hasibuan, M. (2001). Manajemen Sumber Daya Manusia. Jakarta: PT Bumi. Aksara. Hasibuan, S. . M. (2001). Manajemen Sumber Daya Manusia. Jakarta: Bumi Aksara. Kenneth N, D. (1992). Perilaku Organisasi dan Psikologi Personalia. Jakarta: Rineka Cipta. Martoyo, S. (1996). Manajemen sumber Daya Manusia. Jakarta: PT BPFE.

Mink. (1993). Manajemen Sumber Daya Manusia (Kinerja). Jakarta: PT. Elek Media Komputindo.

Noor, S. (2019). Pengaruh Kepemimpinan, Motivasi Kerja, dan Kepuasan Kerja Terhadap Kinerja Personil Polisi Bidokkes Polda Kalimantan Selatan. Relevance, 2, 275-286. Retrieved from http://ejournal.iainsurakarta.ac.id/index.php/relevance/article/view/1869/726

Ratnasari, S. L. (2018). KINERJA KARYAWAN: GAYA KEPEMIMPINAN DAN DISIPLIN KERJA. DIMENSI, 7.

Robbins, S. (1999). Perilaku Organisasi. Jakarta: Prehalindo.

Robbins, S. P. (2002a). Prinsip-Prinsip Perilaku Organisasi (Erlangga, ed.). Jakarta.

Robbins, S. P. (2002b). Prinsip-Prinsip Perilaku Organisasi. Jakarta: Erlangga.

Salovey, P \& Mayer, J. D. (1999). Emotional Inteligence. Jakarta: PT. Gramedia.

Steven, dan H. (n.d.). Prinsip Dasar Kecerdasan Emosional Meraih Sukses. Bandung: PT Mizan Pustaka.

Yadewani, D., \& Wijaya, R. (2019). The relationship between reward, work discipline, motivation and employee job satisfaction among employees of inews tv padang, indonesia. International Journal of Recent Technology and Engineering, 8(2 Special Issue 9). https://doi.org/10.35940/ijrte.B1109.0982S919 